\title{
Tongue Piercing: a Current Trend with High-risk Effects
}

\begin{abstract}
CRISTINA CRENGUTA ALBU ${ }^{1 *}$, STEFAN MILICESCU², STEFAN DIMITRIE ALBU³, GEORGE ION²
'University of Medicine and Pharmacy Carol Davila, Department of Genetics, 37 Dionisie Lupu Str., 020021, Bucharest, Romania 2University of Medicine and Pharmacy Carol Davila, Department of Prosthetic Dentistry, 37 Dionisie Lupu Str., 020021, Bucharest, Romania

3University of Medicine and Pharmacy Carol Davila, Faculty of Dental Medicine, 37 Dionisie Lupu Str., 020021, Bucharest, Romania

Oral and facial piercing as a form of body art are being observed more frequently in medical and dental practices [1]. The use of oral piercings and especially the piercing of the tongue is mainly related to a series of local complications and individuals who decide to use piercings should be aware of such complications [2]. This article presents the dental complications produced by an unusual association between a tongue piercing and tic behavior, along with the implications associated with such a practice.
\end{abstract}

Keywords: tongue piercing, tic behavior, complications, enamel, tooth fractures

Piercing is the practice of puncturing some parts of the body to apply ornamental objects [3]. In recent years, body piercing has increased in popularity and social acceptance [4].

The most common site of piercings is the ear, with increasing popularity involving the mouth, nose, eyebrows, nipples, navel, and genitals $[5,6]$. The mostly pierced oral site is the tongue and the most common form of piercing is the barbell type piercing [7].

Complications of body piercing include immediate and late complications, local and systemic complications and poor cosmesis [2,4].

Immediate complications including pain, swelling and infection are the most serious consequences associated with this procedure [8], while excessive bleeding and pain are the most representative [2].

Late complications related to the piercing insertion site were observed in $97.6 \%$ of cases, with pain, swelling being and foreign body rejection $[2,4]$.

Complications of oral piercings include early post piercing complications and late complications. The type of complication differed significantly according to the piercing location [9].

Generally, the use of oral piercings is related to a series of mainly local complications, like increased salivary flow, oral and dental trauma (tooth fractures), glossitis, halitosis, periodontitis, abscesses (molar abscess and glossal abscess), calculus build-up, dental pain, tongue lacerations and interference with speech, mastication and swallowing $[1,2,8,10]$.

Tongue piercing complications may include hemorrhagia, nerve injury, gingival recession, possible Hepatitis ( $B, C, D$, and $G$ ) contamination, possible HIV infection and tuberculosis transmission, localized infection of the oral and maxillofacial region (acute glossitis, glossal abscess, cephalic tetanus, Ludwig's angina, submandibular Iymphadenitis and submandibular sialadenitis), infections localized remotely to the tongue piercing site (endocarditis, chorioamnionitis and cerebellar abscess), tongue swelling and pain, oral trauma and traumatic dental injuries (mucosal or gingival trauma, chipped or fractured teeth), accidental ingestion or aspiration of the pierce, allergy or hypersensitivity to metal, difficulty in swallowing, and alteration in taste sensations [10 - 13].
As a result, complete information about piercing complications, as well as information about the necessary post-piercing hygiene, should be given to the patient and to the parents of minors [14].

\section{Experimental part}

A female patient aged 22 presents in a private dental practice in Bucharest complaining of fracture and dental sensitivity in the left posterior mandibular area.

During the anamnesis, the patient declared that the pierce had been inserted 10 months ago, in a shop specializing in tattoos and piercings, the insertion having been performed without anesthetic and being painless.

After the rod insertion, the patient needed about 30 days to get used to it, during this period experiencing watery hypersalivation, small disturbances in phonation and mastication and difficult swallowing. The hygiene was maintained only with the help of mouthwash.

The intra-oral examination was performed to assess dental and periodontal conditions, including decayed, missing and filled teeth (DMF-T) index, the degree of gingival inflammation and oral hygiene, enamel damage (e.g. enamel fissures, enamel cracks and grooveshaped abrasions) and periodontal changes (e.g. vestibular and oral gingival recessions) $[15,16]$.

The clinical examination was performed in artificial light, using a dental unit, dental mirror and ball-ended probes, after tooth brushing and air-drying, based on the World Health Organization protocol [17].

The examination of the gingival and periodontal tissues were performed in the following sequence: visual inspection of the gingival tissues to assess the presence or absence of gingival inflammation (by assessing the colour and degree of swelling of the tissues), assessment of the level of oral hygiene (assessing plaque and calculus levels) and assessment of probing depths [18].

Enamel damage was clinically evaluated with a mirror, a probe and an ultraviolet light polymerization lamp under standardized conditions of illumination [15].

\section{Results and discussions}

The clinical intra-oral examination revealed a metalic rod penetrating the tongue from the ventral surface to the dorsal surface, along the midline, in front of the lingual frenulum.

\footnotetext{
* email: crenguta.albu@yahoo.com; Phone +40744544451; The authors contributed equally to the present work and thus are main authors
} 
The rod was made of stainless steel, with two metallic spheres at each end (fig. 1).

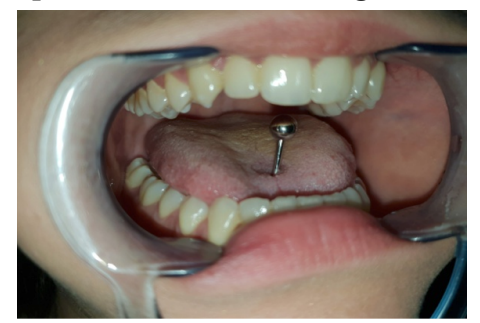

Fig. 1. The aspect of crosstongue pierce: large barbell piercing in the midline of the tongue.

The dental examination also shows a coronary fracture (fissures) that involves the enamel, at the level of the first left mandibular premolar 3.4. (fig. 2).

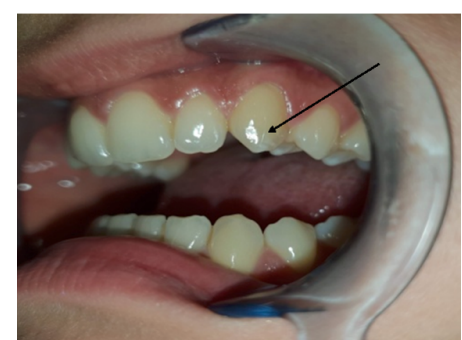

Fig. 2. The enamel fracture at the level of the first left mandibular premolar 3.4

During the anamnesis, the patient admitted that she had acquired a tic behavior of interposing the pierce between the two dental arches and clenching her teeth. After being asked to show how she placed the rod between the dental arches, she placed it exactly at the level of the fracture zone (fig. 3).

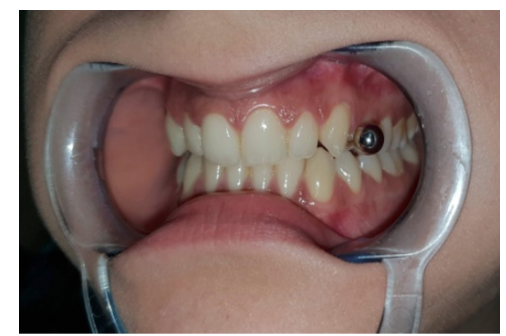

Fig. 3. Position of the rod between the dental arches

Given that the fracture at the level of the first left mandibular premolar 3.4 was a minim one, onlyatenamel level, there was not necessary to rebuild the tooth with composite resin, only the finishing of the enamel prisms and local fluoridation being chosen, followed by case follow-up (fig. 3).

The benefits of fluorides for dental health and resistance of tooth enamel are well known. Fluoride affects enamel properties through the exchange of the hydroxyl group $(-\mathrm{OH})$ in the hydroxyapatite $\mathrm{Ca}_{5}\left(\mathrm{PO}_{4}\right)_{3} \mathrm{OH}$ with a fluoride ion to form either fluorapatite or fluor-hydroxyapatites, who are harder and less soluble when compared to fluoridefree apatite and hence more resistant to acidic environments, which explains the use of fluoride in toothpastes and varnish gels as a means to prevent cariesrelated demineralization [19].

Given that the patient absolutely refused to have the tongue pierce removed, the patient was instructed to try to change her habit of interposing the rod between the arches and of occluding on it, so as to prevent future fractures.

Pierceing application in the month, across the tongue to be exact, is found with increasing frequency in young adults (most of them up to 35 years old).

In case of possible complications due to pierceings and for their own hygiene, the patients come to the dentist.

Special attention must be given to local hygiene, which is similar to that required to the wearers of fixed orthodontic appliances.
The material of the rod is stainless steel, similar to that used in orthodontics for brackets or orthodontic wires. J ust as in the case of fixed orthodontic appliances, it is indicated that teeth brushing and hygiene follow every meal. The stainless steel alloys used as pierce are an austenitic type known as $316 \mathrm{~L}$ archwires (the $\mathrm{L}$ designation denotes a low carbon content) which contain approx. $18 \% \mathrm{Cr}$, and $8 \% \mathrm{Ni}$ (also the exact composition is notclearly mentioned by the manufacturer) [20].

Professionals inserting pierces claim that, since the healing process comes to an end, the pierce can be removed for short time periods and cleansed without the risk that the orifice closes. Once removed, both surfaces of the tongue can be cleaned. Another indication is to avoid hard foods, continuous effort or contact sports while wearing the pierce.

If the patient does not remove the rod for cleansing, a Chlorhexidine mouthwash is recommended.

Chlorhexidine is a synthetic cationic bis-guanide consisting of two symmetric 4-cholorophenyl rings and two biguanide groups connected by a central hexamethylene chain [21].

The most common preparation is the digluconate salt, respectively chlorhexidine digluconate $\left(\mathrm{C}_{34} \mathrm{H}_{54} \mathrm{Cl}_{2} \mathrm{~N}_{10} \mathrm{O}_{14}\right)$, because of its water solubility [22].

Chlorhexidine is an excellent antiplaque agent and possesses very good antimicrobial properties, because it has the ability to kill a wide variety of micro organisms including gram positive and gram negative bacteria (aerobes and anaerobes), fungi and yeasts, in the optimum dose of $20 \mathrm{mg}$ chlorhexidine in a mouthrinse twice daily, equivalent to $10 \mathrm{~mL}$ of $0.2 \%$ chlorhexidine mouthrinse ( 20 $\mathrm{mg}$ ) or $15 \mathrm{~mL}$ of $0.12 \%$ chlorhexidine mouthrinse ( $18 \mathrm{mg}$ ) $[22,23]$.

Also, chlorhexidine use by wearers of fixed orthodontic appliances proved useful, as they decreased plaque deposits and gum inflammation [24].

Although tongue pierces are becoming popular with youth, their consequences can be important: from simple phonation, mastication, deglutition disorders, to tooth fractures or tongue infections. There are literature studies stating that, some patients developed light paresthesias, diminished tongue mobility and decreased taste sensitivity, bleeding, infections or obstructions of the respiratory ways [25-27].

In the case presented, the tongue pierce led to the coronary fracture that involves the enamel, which triggered dental sensitivity, as well as transient disturbances of mastication and deglutition.

Dental enamel is the hardest substance in the human body and serves as the wear-resistant outer layer of the dental crown, forming barrier that protects the tooth from physical, thermal, and chemical agents that would otherwise be injurious to the vital tissue in the underlying dental pulp [28]. Dental enamel cannot regenerate itself, because it is formed by a layer of cells that are lost after the tooth eruption [29].

Treatment for traumatic dental injuries, and particularly for repairing enamel damaged by tongue piercing is very delicate, given that the enamel cannot regenerate itself. Future trend of regenerative dentistry may be the application of genes for enamel synthesis[19, 29].

\section{Conclusions}

This case study report has demonstrated the adverse effects and dental complication associated with tongue piercing and tic behavior. 
According to ADA Statement on Intraoral/Perioral Piercing insertion of tongue piercing is an invasive procedures with numerous negative health sequelae that outweigh any potential benefit [30].

Patients with oral piercings should regularly visit the dentist, thus ensuring the early detection of the side effects and possible oral, dental, and systemic complications associated with this practice.

\section{References}

1. DE MOOR, R., DE WITTE, A., DELME, K., DE BRUYNE, M., HOMMEZ, G. Rev Belge Med Dent. 62, no 2, 2007, p. 104

2. VIEIRA, E.P., RIBEIRO, A.L.R., PINHEIRO, J DE J.V., ALVES, S DE M.J R. J Oral Maxillofac Surg. 69, no 12, 2011, p. 3032

3. GIUCA, M.R., PASINI, M., NASTASIO, S., D'ERCOLE, S., TRIPODI,

D. J Biol Regul Homeost Agents. 26, no 3, 2012, p. 553

4. MELTZER, D.I. Am Fam Physician. 72, no 10, 2005, p. 2029

5. VAN HOOVER, C., RADEMEYER, C.A., FARLEY, C.L. J Midwifery Womens Health. 62, no 5, 2017, p. 521

6. PRESLAR, D., BORGER, J. Body Piercing Infections. In: StatPearls. Treasure Island (FL): StatPearls Publishing; $2019 \mathrm{~J}$ an.

7. INCHINGOLO, F., TATULLO, M., ABENAVOLI, F.M., ET AL. Int. J. Med. Sci. 8, no 8, 2011, p. 649

8. PEJ CIC, A., KOJ OVIC, D., MIRKOVIC, D. West Indian Med J . 61, no 8,2012, p. 838

9. KAPFERER, I., BERGER, K., STUERZ, K., BEIER, U.S. Quintessence Int. 41, no 9, 2010, p. 731

10. YU, C. H., MINNEMA, B. J., GOLD, W. L. Can J Infect Dis Med Microbiol. 21, no 1, 2010, p. e70

11. STEIN, T., J ORDAN, J.D. Tex Dent J. 129, no 7, 2012, p. 687

12. LOPEZ-J ORNET, P., NAVARRO-GUARDIOLA, C., CAMACHOALONSO, F., VICENTE-ORTEGA, V., YANEZ-GASCON, J. Int. J. Dermatol. 45, no 7, 2006, p. 805
13. DYCE, O., BRUNO, J.R., HONG, D., SILVERSTEIN, K., BROWN, M.J., MIRZA, N. Head Neck. 22, no 7, 2000, p. 728

14. GERRETH, K., GERRETH, P. Med Wieku Rozwoj. 14, no 4, 2010, p. 384

15. ADDI, R.A., BENKSIM, A., ZOUINI, M., CHERKAOUI, M. Asian J. Epidemiol. 11, no 1, 2018, p. 14

16. ZIEBOLZ, D., HILDEBRAND, A., PROFF, P., RINKE, S., HORNECKER, E., MAUSBERG, R. F. Clin Oral Investig. 16, no 1, 2012, p. 231

17. KASSAWARA, A.B., TAGLIAFERRO, E.P., CORTELAZZI, K.L., AMBROSANO, G.M., ASSAF, A.V., MENEGHIM, M., PEREIRA, A.C. J Appl Oral Sci. 18, no 2, 2010, p. 116

18. PRESHAW, P.M. BMC Oral Health, 15 (Suppl 1), no S5, 2015, p. 1 19. PANDYA, M., DIEKWISCH, T. Int J Oral Sci. 11, no 1, 2019, p. 8.

20. POP, S.I, DUDESCU, M., BRATU, D.C., POP, R.V., PETRISOR, M., PACURAR, M. Rev. Chim.(Bucharest), 64, no 7, 2013, p. 771

21. GREENSTEIN, G., BERMAN, C., JAFFIN, R. J Periodontol. 57, no 6, 1986, p. 370

22. SAJJAN, P., LAXMINARAYAN, N., KAR, P.P., SAJJANAR, M. OHDM, 15, no 2, 2016, p. 93

23. JAMES, P., WORTHINGTON, H.V., PARNELL, C., HARDING, M., LAMONT, T., CHEUNG, A., WHELTON, H., RILEY, P.. Cochrane Database Syst Rev. 3, no 3, 2017, p. CD008676.

24. BRIGHTMAN, L.J., TEREZHALMY, G.T., GREENW ELL, H., JACOBS, M., ENLOW, D.H. Am J Orthod Dentofacial Orthop. 100, no 4, 1991, p. 324

25. THEODOSSY, T. Br Dent J. 194, no 10, 2003, p. 551

26. BRYAN, S., LIM, J. , MACKENZIE, N. Br Dent J. 216, 2014, no 5, p. 210

27. HEINEN E, BIRKHOLZ P, WILLMES K, NEUSCHAEFER-RUBE C. Logoped Phoniatr Vocol. 42, no 3, 2017, p. 126

28. LACRUZ, R.S., HABELITZ, S., WRIGHT, J.T., PAINE, M.L. Physiol. Rev. 97, no 3, 2017, p. 939

29. JAYASUDHA, BASWARAJ , J., NAVIN, H.K., PRASANNA, K.B. J Clin Diagn Res. 8, no 9, 2014, p. 6

30. ZIEBOLZ, D., STUEHMER, C., VAN NUSS, K., HORNECKER, E., MAUSBERG, R.F. J Contemp Dent Pract. 10, no 6, 2009, p. E065

Manuscript received: 20.09 .2018 